la continuación que exige ese verso debe estar en armonía con él, seguir su caciencia, su tono, el tema que el verso entrega al poeta y a la imaginación, porque ese verso no es sino el motivo poético a desarrollar.

Ese motivo poético se desarrolla del modo que ya hemos tratado de describir en artículos anteriores: por el deseo, por la imaginación, por la meditación, por la insistencia, por lo que se llama trabajo, en fin; escribiendo y recitando una y otra vez el verso, hasta que otro nuevo, esta vez provocado, venga a unirse al primero, y otros a estos dos, hasta terminar el poema, poema cuya gestación y creación ha pasado por los cinco períodos que hemos analizado, o sea:

Período cero: elaboración del ritmo.

1. ${ }^{\circ}$ Aparición del ritmo.

2. Manifestaciones autónomas del ritmo.

3. Formación del verso inicial o matriz.

4. ${ }^{\circ}$ Creación del poema.

El período cero lo hemos estudiado en la primera y segunda parte de estas divagaciones.-M A N E L R O J S.

\title{
El espíritu de la nueva Suiza
}

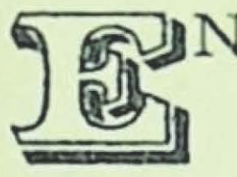

una larga permanencia en Lausaria, conversancio con prestantes hombres de ciencia, leyendo periódicos, observando, he querido tracear lo que es el espíritu de la nueva Suiza, en estos años europeos de reconstrucción moral y material.

Presentaba brillante ocasión para este género de estudios la votación popular, el referendum, que ha tenido lugar en los primeros días del reciente mes de Abril. Esta democracia sana y activa había de aprobar o rechazar una ley que prohibe la fabricación de alcohol de manzana. Ahora bien, los políticos y los predicadores, los moralistas y los periodistas habian intervenido en el debate con ardimiento. Se decía y se demostraba que el consumo de alcohol enflaquecía a la raza y producía una secuela de males: degeneración, cretinismo, deformaciones de varia especie. Una nación de aldeanos, gravemente ligada a la tierra, fuerte y laboriosa iba siendo atrozmente inficionada. Dos intereses combatían, uno, de orden económico, el de las industrias; y otro, de orden moral, el de la salud de la raza. Pues bien, la ética ha triunfado. Serán restringidos la producción y el consumo del alcohol. 
Suiza se presenta de esta suerte, en consonancia con su pasado, austera y grave. En ella dominan siempre preocupaciones de orden moral, tanto en las regiones donde prospera el calvinismo como en las zonas católicas. No se concibe la indiferencia en relación con normas esenciales y nadie aceptaría la doctrina del arte por el arte. Ahora mismo notamos en uno de los mejores representantes de la nueva generación intelectual, fundador y director de la Revue de Genève, en Robert de Traz, ese mismo afán de aguda introspección que nos atrae en el Diario de Amiel. No el vivir fácil, abierto a exteriores influencias, sino la concentración que lleva al misticismo y al diálogo con Dios. Una manera adusta e inquieta donde el escrúpulo penetra e impera, una moral sin complacencias. El gran Alexandre Vinet, nobilísimo pensador que tanta influencia tuvo sobre Sainte Beuve, marida en sus obras los estudios de literatura y las meditaciones cristianas.

Creo que los mismos problemas ligados en otras partes a intereses materiales, tal la oposición entre las clases, se vinculan aquí a la reforma de los espíritus. Cierto es que el comunismo aflora en Basilea por ejemplo; que el patriciado de Friburgo y de Berna ambiciona volver al pasado y limitar las conquistas de la democracia; pero, en suma, esta República sencilla de rústicos sin oligarquía y sin proletariado militante, parece contentarse con la dorada mediocridad recomendada por los clásicos.

Su vida es un constante ejemplo de mesura y de armonía. Países de tradición y de lengua diferentes, de credos antagónicos, conviven sin esfuerzo, discuten con amplia libertad sus aspira.ciones, mantienen el vínculo federal contra toda tendencia centrífuga. Y así, el italiano de Lugano se siente suizo y diferente del vecino del Sur; en Zurich el germanismo presenta matices particulares; Lausana y Ginebra asociadas a Francia se enorgullecen de su originalidad helvética.

Un pequeño y delicioso libro reciente sobre el espíritu de Ginebra, publicado por M. Robert de Traz, nos ofrece la explicación de este arte de acoplar esfuerzos y ajustar voluntades, sin destruir en ellas la originalidad y el ímpetu. No en vano se ha instalado en la metrópoli calvinista la Sociedad de las Naciones. Suiza le ofrece múltiples ejemplos de esa conciliación entre la asociación y la libertad, la independencia y la sinergia, la solidaridad y la variedad. Aquí pueden aprender los put blos inclinados a la discordia interior supremas normas para vivir sin revolución, en armonía, en progreso y en paz.

Ingresamos lentamente en la edad de los «buenos europeos 
agorada por Nietzsche. Este, que vivió tantos años en Basilea y en Sils-Maria encontró seguramente en el país numerosos ejemplares de ellos. La Europa futura que renuncia a erizadas fronteras, que busca agónicamente la unidad, que combate la división y la guerra, va formándose en el seno de esta Suiza pacífica y lenta, estudiosa y sensata.-F R A N C I S C O GA R CÍ A C L DERÓN.

Exclusivo para Atenea en Chile.

\section{La madurez en la literatura}

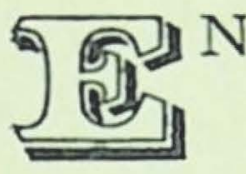

Chile la literatura es una profesión de juventud. Pocos son los escritores de este país que siguen entregados a las letras pasados los años fatales - cuarenta, cincuenta - de los compromisos de familia y del trabajo rudo y hostil. La mayoría abandona la lucha cuando comienza a necesitar ingresos cuantiosos. Un número más pequeño mantiene el entusiasmo hasta que se insinúan en sus cabellos las primeras canas. Son verdaderos héroes de la jornada los que siguen bregando en esa ingrata lid cuando la cabellera es toda de nieve. Si de los cuarenta años del escritor maduro se descuentan los diez primeros de la vida, en que la existencia es simplemente vegetativa y que sólo pueden servir para almacenar ciertos recuerdos que sin esfuerzo - es cierto-puecien izarse a la categoría literaria, quedan sólo treinta de experiencia. En la vida humana esto es poco, y la obra literaria así lo prueba. Mientras tanto, en Europa la literatura es una profesión de madurez. Hace pocos años, Azorín dijo en España que un escritor había dado toda la medida de su talento al cumplir los cuarenta años: Error profundo. La propia obra del maestro de Blanco en azul es un ejemplo. Por muchos que sean los libros interesantes, amenos, admirables en fin, que ha escrito Martínez Ruiz antes de la cuarentena, ¿quién se atrevería a juzgarlo sólo por ellos? Después de sus cuarenta años ha dado los frutos más curiosos. Con sus libros de cuentos, novelas y obras teatrales de hoy ha. levantado polémicas y despertado la atención de propios y extraños. Es decir, ha hecho obra de juventud.

Es que en Europa, como la literatura es una profesión, el literato puede entregarle lo mejor de sus días. Cuando joven, el hombre pone en las letras mucha pasión, mucho fuego, y eso está bien; pero también hace de ellas un vehículo de sus erro- 